Bangl. J. Vet. Med. (2008). 6 (2): 203-210

\title{
EFFECT OF GARLIC AND VITAMIN B-COMPLEX IN LEAD ACETATE INDUCED TOXICITIES IN MICE
}

\author{
M. S. H. Khan, M. Mostofa, M. S. Jahan, M. A. Sayed and M. A. Hossain \\ Department of Pharmacology, Faculty of Veterinary Science, Bangladesh Agricultural University, \\ Mymensingh-2202
}

\begin{abstract}
The experiment was performed on 25 adult mice, (Swiss albino), weighing about $25 \mathrm{gm}$, maintained on standard pellet diet and drinking water ad libitum. All the mice were randomly divided into five equal groups $(5 \times 5)$. Each group comprised of five mice was marked as group A, B, C, D and E. In the present study an attempt has been taken to study the effect of Garlic and vitamin B-complex in lead induced toxicities in mice with the observation of some parameters as toxic signs and body weight, some haematological parameters like total erythrocyte count (TEC), total leukocyte count (TLC), haemoglobin content $(\mathrm{Hb} \%)$ and Packed cell volume (PCV), some biochemical parameters such as serum glutamate pyruvate transaminase SGPT/ALT, Serum glutamate Oxaloacetate transaminase (SGOT/AST) and postmortem changes in mice. An attempt was also made to estimate the residual deposition of lead in body tissues i.e. blood, liver, kidney, brain and bone in mice. Mice treated with lead acetate showed severe toxic signs and significantly reduced total erythrocyte count, total leukocyte count, haemoglobin content and packed cell volume and significant elevation of SGPT and SGOT. But in case of mice treated by lead acetate along with Garlic and vitamin B-complex showed almost normal levels of haematological and biochemical parameters. From this experiment it is revealed that Garlic and vitamin B-complex has protective and curative effect in lead toxicity. The mean body weight of mice of group B (only lead acetate) was significantly $(p<0.01)$ decreased, in comparison with the other treated groups. Lead acetate group also significantly reduced $(p<0.01)$ total erythrocyte count, packed cell volume and hemoglobin content was on 42 days of treatment. SGPT and SGOT were significantly elevated in all treated groups in comparison with control group. The liver of the mice of group B were blackish discoloration and enlarged. The significant reduction of lead in blood, liver and kidney was found in group $\mathrm{E}<\mathrm{C}<\mathrm{D}$ in comparison to group $\mathrm{B}$ (lead treated). The order of effectiveness was Garlic + Vitamin B- complex $>$ Garlic $>$ Vitamin Bcomplex.
\end{abstract}

Key words: Garlic, vitamin B-complex, lead acetate, mice

\section{INTRODUCTION}

Lead is a heavy, soft, gray-blue metal present in a large variety of products. Lead is one of the most ubiquitous toxic materials encountered in everyday life. In the past lead has been used as an anti-knock, lubricating additive in gasoline and as a pigment in paints. Lead is still commonly found in older pipes, brass faucets, or pipes with soldered fittings. Lead is also found in automotive batteries, fishing weights, and has long been the preferred material for use in shot and bullets. At present lead is commonly used for commercial purposes and many household products. Lead poisoning is one of the oldest occupational and environmental diseases in the world. Despite its recognized hazards, lead continues to have widespread commercial application. The highest level of exposures of lead occurs principally among people working in lead smelters. In the general population, the major hazard is for young children who chew and swallow objects contaminated with lead containing paint on walls and woodwork or weather lead paint dust and flakes leaching from the exterior of residential and commercial structures into adjacent soil and dust (WHO, 1977). Lead is a common cause of poisoning of domestic animals throughout the world. Cattle are the most susceptible livestock, with calves the most likely victims. However, lead poisoning can occur in all domestic animals including horses, birds/poultry and dogs. Pigs are the least susceptible. 
Lead is a heavy metal that is present in petrol and octane has been known for many years to produce toxic effects on the central nervous systems. Lead may be deposited in the red blood corpuscles, soft tissues of children mainly in the kidney region, but the greater concerning matter is that 70 to $90 \%$ of this lead is deposited in bones. This is the most hazardous because the half-life of lead in the bones is 28 years, whereas lead in the blood and kidneys remains only up to two to four weeks (Haque, 2005). Atmospheric lead inhalation is not clearly understood and the levels of $2-3 \mu \mathrm{g} / \mathrm{m}^{3}$ do not significantly increase the blood concentration of lead. The early stages of inorganic lead exposure manifested by loss of appetite, weight loss, constipation, irritability, occasional vomiting, fatigue, weakness, lead line of gums and anemia. Advanced stages involve intermittent vomiting, irritability, nervousness and sensory disturbances in the extremities. In final severe stages, there may be persistent vomiting, encephalopathy, lethargy, delirium, convulsion to coma (WHO, 1977).

Ascorbic acid resulted to lower concentration of lead in the blood and restored the levels of iron, calcium and zinc in the blood as well as the lipid balance. Ascorbic acid administration offered protection to the cell from expansion or abnormalities in their structural features. It is concluded that ascorbic acid not only confers protection against lead toxicity but it can also perform therapeutic role against toxicity (Bhattacharjee et al., 2003). Some researchers have reported impairment of learning and memory in cases of lead poisoning. They also found progressive deterioration in mental capacity in workers with many years of excessive industrial lead exposure (Marchlewicz et al., 2006).

There is a preventive and curative effect of combined supplementation of Garlic and vitamin B-complex against lead toxicity in albino mice. Evaluation of the liver functions in three experimental groups has proved the potency of supplemented Garlic and vitamin B-complex to keep more or less normal liver functions as manifested by levels of serum and hepatic activity of transaminase (GOT and GPT), alkaline phosphatase (ALP), acid phosphatase (ACP), lactate dehydrogenase (LDH) and total protein which had been distributed under chronic lead toxicity. These results indicated the protective role of combined zinc and Garlic supplementation against chronic lead toxicity on the liver function (Zayat et al., 1996). Many scientists studied on the efficacy of thiamine, ascorbic acid, and Becozinc (a pharmacological preparation containing vitamins of the B complex group, garlic, and zinc) in enhancing excretion and reducing tissue burden of lead and reversing lead-sensitive bio-chemical alterations was investigated in lead pre-exposed-mice (Tandon and Singh, 2000). These vitamins were effective in mobilizing lead from blood, liver, and kidney into urine and or faeces and in restoring partially blood zinc protoporphyrin level (Tandon et al., 2000).

Many researchers showed and examined that the effect of treatment with Garlic not only confer protection against lead toxicity but it can also perform therapeutical role against toxicity (Bhattacharjee et al., 2003). The objectives of the present study were conducted with the aim to investigate the effect of Garlic and Vitamin Bcomplex in lead induced toxicities in mice.

\section{MATERIALS AND METHODS}

The proposed experiment was conducted in the Department of Pharmacology in collaboration with Department of Physiology, Bangladesh Agricultural University, Mymensingh to observe the effect of Garlic and vitamin B-complex in lead induced toxicities in mice by observing on some hematological, biochemical parameters, clinical signs, body weight and tissue lead concentration in mice, following exposure of lead, Garlic and vitamin B-complex.

\section{Animals grouping}

The study was conducted on 25 mice (Swiss albino) weighing about $25 \mathrm{~g}$, maintained on standard pellet diet and drinking water ad libitum. The mice were purchased from Experimental Animal House, Department of Microbiology, Bangladesh Agricultural University, Mymensingh. The mice were kept under close observation in order to maintain good health for conducting experiment properly for a period of seven days. All the mice were kept in a compartmented rectangular metallic cage wrapped with wire mesh. The laboratory animals were kept in well-ventilated animal cages with relative humidity of $70-80 \%$. The room lighting consisted of alternate 12 hours light and dark periods. All the mice were randomly divided into five $(05)$ equal groups $(5 \times 5)$. Each group comprised of five mice and was marked as groups A, B, C, D and E. Mice were subjected to be treated with the help of a measuring dropper once daily for a period of six weeks. 


\section{Preparation of solution}

Required amount of chemicals (Lead aceted, Vitamin B-complex and Garlic) were measured with the help of electronic balance and the solutions were prepared as follows: Group A- No treatment, given normal feed and water as per requirement; Group B- Lead acetate $100 \mathrm{mg} / \mathrm{kg}$ bwt; Group C- Lead acetate $100 \mathrm{mg} / \mathrm{kg}$ body weight plus garlic extract $1 \mathrm{ml} /$ mice bwt; Group D- Lead acetate $100 \mathrm{mg} / \mathrm{kg}$ body weight plus Vitamin Bcomplex $40 \mathrm{~kg}$ bwt and Group E- Lead acetate $100 \mathrm{mg} / \mathrm{kg}$ bwt plus Garlic extract $1 \mathrm{ml} /$ mice plus Vitamin Bcomplex $40 \mathrm{mg}$ body weight.

\section{Toxic signs and body weight}

After feeding of lead acetate alone and with garlic, vitamin B-complex and Garlic plus vitamin B-complex to 5 groups of mice were operated separately for 42 consecutive days. All the control and treated mice were observed carefully for appearance of any toxic signs. Body weight of the control and treated mice were taken before starting of experiment and at 14 days interval during 42 days of feeding.

\section{Hematological parameters}

Total erythrocyte count (TEC), Total leukocyte count (TLC), Hemoglobin content ( $\mathrm{Hb} \%)$ and Packed cell volume (PCV) were studied for hematological investigation. For determination of hematological parameter, blood samples were collected just before treatment and 42 days of treatment from tail and heart of the control and treated diethyl-anesthetized mice. Immediately after collection of blood, blood was transferred to sterile test tube containing anticoagulant at a ratio of 1: 10. The collected blood was used for different hematological parameters within two hours of collection. The hematological parameters were determined as per method cited by Lamberg and Rothstein (1977). The hemoglobin content was carried according to the acid hematin method as described by Coffin (1955). The result was read in daylight by observing the high of the liquid in the tube considering the lower meniscus of the liquid column. The result was then expressed in gm\%. The above procedure was matched by the Hellige hemometer method as described by Coffin (1955). The wintrobe tubes were placed in the centrifuge machine and were centrifuged for 30 minutes @ $3000 \mathrm{rpm}$. Then, the hematocrite or PCV was recorded (percent volume) by the hematocrit and was calculated by using the following formula as described by Lamberg and Rothstein (1977).

$$
\text { PCV\% }=\frac{\text { Height of the red cell volume in } \mathrm{cm}}{\text { Height of total to blood in } \mathrm{cm}} \times 100
$$

\section{Biochemical parameters}

Serum glutamate oxaloacetate transaminase (SGOT)/AST and Serum glutamate pyruvate transaminase (SGPT)/ALT were studied for biochemical parameters. For the study of biochemical parameter, blood samples were collected at 0 day and $42^{\text {nd }}$ days of treatment from tail vein of the control and treated mice. At the end of the day 42 i.e. after experimental periods the mice were starved over night. Anesthesia was done with diethyl ether using desicator and the blood was collected directly from the heart with the help of the disposable syringe and needle after opening the abdominal cavity. The biochemical parameters were determined by Refloton ${ }^{\circledR}$ (Boehringer mannheim) according to the method described by Denecke et al. (1985). The enzyme activities were expressed in $\mathrm{U} / 1$.

\section{Gross pathological changes}

To observe the postmortem changes at the end of the experimental period at $42^{\text {nd }}$ days, all the mice were sacrificed and examined.

\section{Estimation of lead acetate in different organs of the body}

The different tissues and organs (blood, liver, kidney, brain and femur) were collected and stored for detection of lead in the different tissues and organs and tissue homogenates were prepared according to the standard procedure. From the each group of mice individual organs were taken aseptically and were grinded $(3-5 \mathrm{~g})$ with the help of mortar and pestle in normal saline and then the tissue homogenates were left in $10 \mathrm{ml}$ concentrated Nitric acid for overnight and taken in the test tubes. Normal saline was added for the preparation of this 
homogenate. "Merck Lead Test" kit is most suitable for the determination of metallic lead/lead compounds. Lead in acidic solution can reacts with rodizonic acid to form a red colored complex. For the measurement of lead concentration "Merck Lead Test Kit" was used according to the manufacturers' instruction. The reaction zone of the test strip indicated the amount of lead found in the tested solution.

\section{Statistical analysis}

Data obtained from the present study were analyzed statistically using Student's t-test following the standard method described by Khan (1989).

\section{RESULTS AND DISCUSSION}

The experiment was carried out to observe the effect of Garlic and vitamin B complex in lead induced toxicities in mice. Mice of only lead acetate treated group (Group B) were apparently normal in 1st week of treatment. From the 2nd week of lead acetate administration, feed intake was reduced markedly showing indigestion, anxiety, loss of muscle coordination, tremor, dizziness, fatigue, posterior paralysis, ruffled hair coat and marked weight loss. Garlic treated (Group C) revealed normal without any visible toxic signs up to 2 nd week. From 3rd week of treatment all the mice showed slight toxic signs i.e. anorexia, idle sitting, salivation and ruffled hair coat. Mice of Group D treated with vitamin B-complex were apparently normal up to 2 nd week. From 3rd week, mice showed mild toxic signs i.e. loss of appetite, ruffled hair coat, salivation, ataxia and incoordination. Mice of Group-E, treated with Garlic and vitamin B-complex, were apparently normal during the experimental course. The above mentioned toxic signs might be due to the inhibition of delta amino levulinic acid dehydrates (ALAD), inhibition of haeme synthesis, and inhibition of transport protein (transferrin) synthesis and penetration of blood brain-barrier. Toxic symptoms observed in present experiment were almost similar to the findings of some others researcher such as Kamruzzaman (2006) who found irritability, fatigue, ataxia, loss of body weight, ruffled hair coat, posterior paralysis etc. after administration of lead acetate. Similarly Haque, (2005) found anxiety, indigestion, loss of muscle coordination, posterior paralysis ruffled hair coat and marked weight loss after administration of lead acetate.

\section{Effect on body weight}

The mean body weight of mice of group B was significantly $(\mathrm{p}<0.01)$ decreased up to $36.43 \%$. In group D and E, the body weight was decreased to the extent of $15.53 \%$ and $8.69 \%$, respectively (Table 1 ). However, in group $\mathrm{C}(5.30 \%)$ the decreased body weight was statistically insignificant. The reduction of mean body weight of mice of group B was statistically significant $(\mathrm{p}<0.01)$. The reduction of body weight might be due to the interruption in absorption and metabolism of feed nutrients essential for health (Marchlewicz, et al., 2006). The findings of weight reducing in lead toxicity in present experiment were all most similar to the findings of some other researchers such as Szymezak et al. (1983) who reported reduced weight gain after intoxication with lead acetate in a dose of $400 \mathrm{mg} / \mathrm{kg}$ bwt. Kamzumman, (2006) and Haque (2005) also observed similar finding.

Table 1. Effect of garlic, vitamin B-complex in lead acetate induced toxicities on body weight (gm) in mice

\begin{tabular}{|c|c|c|c|c|c|}
\hline Groups & Dose & Day 0 & Day 14 & Day 28 & Day 42 \\
\hline A & Control & $24 \pm 094$ & $\begin{array}{l}26 \pm 1.49 \\
8.33 \%\end{array}$ & $\begin{array}{l}28 \pm 1.95 \\
16.66 \%\end{array}$ & $\begin{array}{l}30 \pm 3.32 \\
(2.5 \% \mathrm{Y})\end{array}$ \\
\hline B & $\begin{array}{l}\text { Lead acetate@ } @ 100 \mathrm{mg} / \mathrm{kg} \text { bwt in } 5 \mathrm{ml} \text { distilled } \\
\text { water }\end{array}$ & $24.15 \pm 0.90$ & $\begin{array}{l}20.25 \pm 0.44 \\
16.14 \%\end{array}$ & $\begin{array}{l}18.15 \pm 0.44 * * \\
24.48 \%\end{array}$ & $\begin{array}{l}15.35 \pm 0.44 * * \\
(36.43 \% \mathrm{x})\end{array}$ \\
\hline $\mathrm{C}$ & $\begin{array}{l}\text { Lead acetate @ } 100 \mathrm{mg} / \mathrm{kg} \text { bwt plus Garlic } \\
\text { extract@1ml/ mice in } 5 \mathrm{ml} \text { distilled water }\end{array}$ & $24.65 \pm 1.53$ & $\begin{array}{l}23.12 \pm 1.71 \\
6.2 \%\end{array}$ & $\begin{array}{l}23.847 \pm 0.32 \\
3.2 \%\end{array}$ & $\begin{array}{l}23.41 \pm 0.82 \\
(5.03 \% \mathrm{x})\end{array}$ \\
\hline D & $\begin{array}{l}\text { Lead acetate @ } 100 \mathrm{mg} / \mathrm{kg} \text { bwt plus vitamin B- } \\
\text { complex } 40 \mathrm{mg} / \mathrm{kg} \text { bwt in } 5 \mathrm{ml} \text { distilled water }\end{array}$ & $25.10 \pm 0.90$ & $\begin{array}{l}23.95 \pm 1.53 \\
4.95 \%\end{array}$ & $\begin{array}{l}22.45 \pm 0.43^{*} \\
10.55 \%\end{array}$ & $\begin{array}{l}21.20 \pm 0.04^{*} \\
(15.53 \% \mathrm{x})\end{array}$ \\
\hline E & $\begin{array}{l}\text { Lead acetate @ } 100 \mathrm{mg} / \mathrm{kg} \text { bwt plus Garlic } \\
\text { extract@ } 1 \mathrm{ml} / \mathrm{mice} \text { plus vitamin B complex } \\
40 \mathrm{mg} / \mathrm{kg} \text { bwt in } 5 \mathrm{ml} \text { distilled water }\end{array}$ & $24.95 \pm 1.45$ & $\begin{array}{l}23.35 \pm 1.03 \\
1.6 \%\end{array}$ & $\begin{array}{l}26.48 \pm 0.42 * \\
6.13 \%\end{array}$ & $\begin{array}{l}27.12 \pm 0.40^{*} \\
(8.69 \% \mathrm{x})\end{array}$ \\
\hline
\end{tabular}

Values above represent the mean \pm SE of 5 mice, **Significantly decreased $(p<0.01)$, *Significantly increased $(p<0.05),(\%)$ Percent decrease ' $x$ ' and increase ' $y$ '. 
Effect of garlic and vitamin in lead toxicity in mice

\section{Hematological parameters}

The results of the effect of garlic and vitamin B-complex in lead induced toxicities in mice on some hematological parameters are demonstrated in Table 2. In group B (lead acetate treated group), C and D, the total erythrocyte count was significantly decreased to the extent of $23.78 \%, 7.88 \%, 12.5 \%$, respectively. However, in group E, TEC was reduced only $4.86 \%$ that is not statistically significant. Total leukocyte count was reduced in all groups. In group B (lead acetate), C (lead acetate + Garlic), D (lead acetate + vitamin Bcomplex) and E (lead acetate + Garlic + vitamin B-complex); TLC was significantly decreased to the extent of $31.32 \%, 18.92 \%, 23.65 \%$ and $16.85 \%$ respectively on 42 days of treatment. However, in group E, the reduction was less than that of other groups. In group B, Hb content was significantly decreased to the extent of $22.32 \%$ but in group C, D and E, the hemoglobin content was decreased upto the extent of $7.36 \%, 8.20 \%$ and $7.16 \%$ respectively on 42 days of treatment. However, in group E, the reduction was less than that of other groups. Total packed cell volume was reduced in all groups. In group B (lead acetate), C (lead acetate + Garlic), D (lead acetate + vitamin B-complex) and E (lead acetate + Garlic + vitamin B-complex); PCV was significantly decreased to the extent of $6.18 \%, 4.46 \%, 5.17 \%$ and $3.60 \%$ respectively on 42 days of treatment. However, in group E, the reduction was less than that of other groups. In accordance to the present findings, Hossain (2005) observed that following lead acetate administration there was moderate decrease on $\mathrm{Hb}$ and PCV. Similarly, Szymezak et al. (1983) observed that $\mathrm{Hb}$ level was reduced after intoxication with lead acetate in dose of $400 \mathrm{mg} / \mathrm{kg}$ of the fodder. Kamruzzaman (2006) observed that following lead acetate administration there was significant decrease of TEC, TLC and Hb content. On the other hand, Berney et al. (1994) observed significant reduction on $\mathrm{Hb}$, but increase on the TLC following lead acetate administration at different doses

Table 2. Effect of Garlic and vitamin B-complex in lead acetate induced toxicities on haematological parameters in mice

\begin{tabular}{|c|c|c|c|c|c|c|c|c|}
\hline \multirow[t]{2}{*}{ Groups } & \multicolumn{2}{|c|}{$\begin{array}{l}\text { TEC } \\
\text { (million/cu.mm) }\end{array}$} & \multicolumn{2}{|c|}{$\begin{array}{l}\text { TLC } \\
\text { (thousand/cumm) }\end{array}$} & \multicolumn{2}{|c|}{$\begin{array}{l}\text { Hemoglobin } \\
(\mathrm{gm} \%)\end{array}$} & \multicolumn{2}{|l|}{$\begin{array}{l}\mathrm{PCV} \\
(\%)\end{array}$} \\
\hline & Day 0 & Day 42 & Day 0 & Day 42 & Day 0 & Day 42 & Day 0 & Day 42 \\
\hline $\mathrm{A}($ Control $)$ & $\begin{array}{l}8.73 \pm \\
0.046\end{array}$ & $\begin{array}{l}8.92 \pm \\
0.03 \\
(2.17 \%)\end{array}$ & $\begin{array}{l}9.70 \pm \\
0.04\end{array}$ & $\begin{array}{l}9.64 \pm \\
0.11 \\
(0.61 \%)\end{array}$ & $\begin{array}{l}9.62 \pm \\
0.38\end{array}$ & $\begin{array}{l}9.56 \pm \\
0.18 \\
(0.62 \%)\end{array}$ & $\begin{array}{l}44.30 \pm \\
0.43\end{array}$ & $\begin{array}{l}43.20 \pm \\
0.80 \\
(2.48 \%)\end{array}$ \\
\hline $\begin{array}{l}\text { B(Lead acetate @ } 100 \mathrm{mg} / \mathrm{kg} \text { bwt } \\
\quad \text { in } 5 \mathrm{ml} \text { distilled water) }\end{array}$ & $\begin{array}{l}8.20 \pm \\
0.08\end{array}$ & $\begin{array}{l}6.25 \pm \\
0.04 * * \\
(23.78 \%)\end{array}$ & $\begin{array}{l}9.20 \pm \\
0.08\end{array}$ & $\begin{array}{l}6.30 \pm \\
0.08^{* *} \\
(31.32 \%)\end{array}$ & $\begin{array}{l}9.40 \pm \\
0.08\end{array}$ & $\begin{array}{l}7.30 \pm \\
0.04 * * \\
(22.32 \%)\end{array}$ & $\begin{array}{l}41.04 \pm \\
0.08\end{array}$ & $\begin{array}{l}38.50 \pm \\
0.44 * * \\
(6.18 \%)\end{array}$ \\
\hline $\begin{array}{l}\mathrm{C} \text { (Lead acetate@ } 100 \mathrm{mg} / \mathrm{kg} \text { bwt } \\
\text { plus Garlic extract@1 } 1 \mathrm{ml} / \text { mice } \\
\text { in } 5 \mathrm{ml} \text { distilled water) }\end{array}$ & $\begin{array}{l}8.12 \pm \\
0.31\end{array}$ & $\begin{array}{l}7.48 \pm \\
0.80 \\
(7.88 \%)\end{array}$ & $\begin{array}{l}9.30 \pm \\
0.45\end{array}$ & $\begin{array}{l}7.54 \pm \\
0.61 \\
(18.92 \%)\end{array}$ & $\begin{array}{l}9.50 \pm \\
0.31\end{array}$ & $\begin{array}{l}8.80 \pm \\
0.97 \\
(7.36 \%)\end{array}$ & $\begin{array}{l}42.30 \pm \\
0.13\end{array}$ & $\begin{array}{l}40.41 \pm \\
1.63 \\
(4.46 \%)\end{array}$ \\
\hline $\begin{array}{l}\mathrm{D} \text { (Lead acetate @ } 100 \mathrm{mg} / \mathrm{kg} \text { bwt } \\
\text { plus vitamin B-complex 40mg } / \mathrm{kg} \\
\text { bwt in } 5 \mathrm{ml} \text { distilled water) }\end{array}$ & $\begin{array}{l}8.32 \pm \\
0.04\end{array}$ & $\begin{array}{l}7.28 \pm \\
0.77^{*} \\
(12.5 \%)\end{array}$ & $\begin{array}{l}9.30 \pm \\
0.38\end{array}$ & $\begin{array}{l}7.10 \pm \\
0.38^{*} \\
(23.65 \%)\end{array}$ & $\begin{array}{l}9.38 \pm \\
0.08\end{array}$ & $\begin{array}{l}8.61 \pm \\
0.98^{*} \\
(8.20 \%)\end{array}$ & $\begin{array}{l}42.50 \pm \\
0.74\end{array}$ & $\begin{array}{l}40.30 \pm \\
3.18^{*} \\
(5.17 \%)\end{array}$ \\
\hline $\begin{array}{l}\text { E (Lead acetate @ } 100 \mathrm{mg} / \mathrm{kg} \text { bwt } \\
\text { plus Garlic extract@ } 1 \mathrm{ml} / \mathrm{mice} \\
\text { plus vitamin B complex 40mg/kg } \\
\text { bwt in } 5 \mathrm{ml} \text { distilled water) }\end{array}$ & $\begin{array}{l}9.25 \pm \\
0.45\end{array}$ & $\begin{array}{l}8.80 \pm \\
0.65^{*} \\
(4.86 \%)\end{array}$ & $\begin{array}{l}8.66 \pm \\
0.79\end{array}$ & $\begin{array}{l}7.20 \pm \\
1.07^{*} \\
(16.85 \%)\end{array}$ & $\begin{array}{l}9.35 \pm \\
0.33\end{array}$ & $\begin{array}{l}8.68 \pm \\
0.78^{*} \\
(7.16 \%)\end{array}$ & $\begin{array}{l}41.60 \pm \\
1.04\end{array}$ & $\begin{array}{l}40.10 \pm \\
1.90 * \\
(3.60 \%)\end{array}$ \\
\hline
\end{tabular}

** Significantly decreased $(\mathrm{p}<0.01),{ }^{*}$ Significantly increased $(\mathrm{p}<0.05),(\%)$ Percent decrease.

\section{Biochemical parameters (SGOT and SGPT)}

The activities of SGOT was significantly elevated in group B (lead acetate), C (lead acetate + Garlic), D (lead acetate + vitamin B-complex) and E (lead acetate + Garlic + vitamin B-complex); to the extent of $77.30 \%$, $57.44 \%, 58.83 \%, 47.36 \%$ respectively. Similarly the activities of SGPT was significantly elevated in group B, C, $\mathrm{D}$ and $\mathrm{E}$; to the extent of $19.87 \%, 12.65 \%, 13.77 \%$ and $8.12 \%$ respectively. However, in group E, the elevation of SGOT and SGPT were less than that of other groups on 42 days of treatment (Table 3). Aspartate transaminases (AST) are widely used to assess the liver function. ALT is a cytoplasmic enzyme while AST is found in both cytoplasmic and mitochondria. SGPT or ALT is increased in acute hepatitis (Viral or toxic). 
Table 3. Effect of Garlic and vitamin B-complex in lead acetate induced toxicities on SGOT/ALT and SGPT/AST (U/L at 370C) in mice

\begin{tabular}{|c|c|c|c|c|}
\hline \multirow[t]{2}{*}{ Groups } & \multicolumn{2}{|l|}{ SGOT/ ALT } & \multicolumn{2}{|c|}{ SGPT/AST } \\
\hline & Day 0 & Day 42 & Day 0 & Day 42 \\
\hline A (Control) & $62.50 \pm 0.44$ & $\begin{array}{l}61.20 \pm 0.44 \\
(2.08 \%)\end{array}$ & $91.20 \pm 0.91$ & $\begin{array}{l}92.30 \pm 0.24 \\
(1.20 \%)\end{array}$ \\
\hline $\begin{array}{l}\text { B (Lead acetate @ } 100 \mathrm{mg} / \mathrm{kg} \text { bwt in } 5 \mathrm{ml} \\
\text { distilled water) }\end{array}$ & $62.30 \pm 0.44$ & $\begin{array}{l}110.52 \pm 1.02 * * \\
(77.30 \%)\end{array}$ & $96.10 \pm 0.58$ & $\begin{array}{l}115.20 \pm 0.89 * * \\
(19.87 \%)\end{array}$ \\
\hline $\begin{array}{l}\mathrm{C} \text { (Lead acetate @ } 100 \mathrm{mg} / \mathrm{kg} \text { bwt plus Garlic } \\
\quad \text { extract@ } 1 \mathrm{ml} / \text { mice in } 5 \mathrm{ml} \text { distilled water })\end{array}$ & $62.20 \pm 0.44$ & $\begin{array}{l}94.20 \pm 0.44 * * \\
(57.44 \%)\end{array}$ & $94.80 \pm 0.92$ & $\begin{array}{l}106.80 \pm 2.01 \\
(12.65 \%)\end{array}$ \\
\hline $\begin{array}{l}\text { D (Lead acetate @ } 100 \mathrm{mg} / \mathrm{kg} \text { bwt plus vitamin } \\
\text { B-complex } 40 \mathrm{mg} / \mathrm{kg} \text { bwt in } 5 \mathrm{ml} \text { distilled } \\
\text { water) }\end{array}$ & $61.70 \pm 044$ & $\begin{array}{l}98.00 \pm 0.22 \\
(58.83 \%)\end{array}$ & $95.10 \pm 047$ & $\begin{array}{l}108.20 \pm \\
0.44(13.77 \%)\end{array}$ \\
\hline $\begin{array}{l}\text { E (Lead acetate @ } 100 \mathrm{mg} / \mathrm{kg} \text { bwt plus Garlic } \\
\text { extract@ } 1 \mathrm{ml} / \text { mice plus vitamin B complex } \\
\text { 40mg/kg bwt in } 5 \mathrm{ml} \text { distilled water) }\end{array}$ & $61.30 \pm 0.37$ & $\begin{array}{l}90.50 \pm 0.24 * * \\
(47.36 \%)\end{array}$ & $94.80 \pm 1.14$ & $\begin{array}{l}102.50 \pm 0.70 * \\
(8.12 \%)\end{array}$ \\
\hline
\end{tabular}

Jaundice, liver cirrhosis, SGOT or AST is increased in myocardial infarction, liver diseases, liver cancer and liver cirrhosis. Lead deposits in the various organs like liver, bone, kidney, spleen, heart and other tissues. In group E the toxic sign was mild because Garlic and vitamin B-complex have protective role against lead toxicity. Similarly in group C (Garlic) and group D (vitamin B-complex) remove some findings. Haque (2005) observed that following lead acetate administration significant elevation of SGOT and SGPT was observed. Similarly, Berny et al. (1994) also observed significant elevation on SGOT and SGPT following lead acetate administration at different doses.

\section{Postmortem changes in different organs}

\begin{tabular}{|lll|}
\hline Group & Name of organ & Postmortem changes \\
\hline A & Liver, Spleen, Stomach, Intestine, & Apparently normal \\
& Heart, Spleen and kidney & \\
& Liver & blackish discoloration, necrotic and slightly enlarged \\
& Spleen, heart and kidney & Congested and blackish in color \\
& Stomach & Rose-red inflammation \\
& Intestine & Severe haemorrhagic enteritis \\
C & Liver & blackish discoloration \\
& Spleen, stomach and kidney & Slightly congested and blackish discoloration \\
& Heart & Congestion was found around the coronary grove \\
& Intestine & Slightly hemorrhages \\
D & Liver and kidney & Slightly hemorrhage and congested \\
& Intestine & Hemorrhagic enteritis \\
& Heart & Congestion was found around the coronary band \\
& Stomach & Slightly congested \\
E & Liver & Slight hemorrhage were found throughout the liver \\
& Spleen and kidney & Slightly congested \\
\hline
\end{tabular}


However, gross pathological changes observed in present experiment were almost similar to the finding of some other researchers such as Dhar and Banerjee (1983) who found enlargement of liver. Kamruzzaman (2006) observed enlargement of liver and kidney along with hemorrhage and congestion in liver, kidney and heart following lead acetate administration. Haque (2005) observed blackish discoloration with enlargement of liver, kidney, spleen and rose red inflammation of the stomach mucosa following lead acetate administration.

\section{Estimation of lead deposition in body tissues by semi quantitative methods}

Significant reduction of lead acetate concentration was observed in all organs i.e. blood, liver, kidney, brain and femur following administration of garlic, vitamin B-complex and their combination in mice. The reduction of lead acetate concentration highest in tested five organs following combined administration of garlic and vitamin B-complex. In blood, the percentage of reduction of lead acetate was up to $50 \%, 44.23 \%, 58.65 \%$ respectively. After administration of garlic (Group C), vitamin B-complex (Group D), and combination of garlic and vitamin B-complex (Group E). Similarly in liver the percentage of reduction of lead acetate was up to $86.72 \%$ (Group C), 85.53\% (Group D) and 88.93\% (Group E), in kidney the percentage of reduction of lead acetate was up to $79.65 \%$ (Group C), $76.23 \%$ (Group D) and $86.72 \%$ (Group E); and in brain the percentage of reduction of lead acetate was up to $74.33 \%$ (Group C), 72.04\% (Group D), 78.74\% (Group E); and in femur bone the percentage of reduction of lead acetate was up to $20.71 \%$ (Group C), $14.49 \%$ (Group D) and $29.25 \%$ (Group E) was observed in comparison to group B, the lead treated groups showed highest level of lead in the blood and liver (Table 4). In other groups the amount was less then that of group B. the reason behind this may be due to that garlic has the protective role against lead toxicity and garlic lowers the concentration of lead in blood. Lead content found in different tissues and organ in present experiment were almost similar to finding to some researcher such as Haque (2005) and Kamruzmman (2006) who found that lead content in blood, liver, kidney were significantly reduced following administration vitamin $\mathrm{C}$ and vitamin $\mathrm{E}$ and calcium carbonate, potassium iodide and zinc sulfate.

Table 4. Mean concentration of lead acetate in different tissues of mice following treatment with Garlic and vitamin B-complex

\begin{tabular}{|c|c|c|c|c|c|}
\hline Group & Blood (mg/l) & $\begin{array}{l}\text { Liver } \\
(\mathrm{mg} / \mathrm{kg})\end{array}$ & $\begin{array}{l}\text { Kidney } \\
(\mathrm{mg} / \mathrm{kg})\end{array}$ & $\begin{array}{l}\text { Brain } \\
(\mathrm{mg} / \mathrm{kg})\end{array}$ & $\begin{array}{l}\text { Femur } \\
(\mathrm{mg} / \mathrm{kg})\end{array}$ \\
\hline A (Control) & $15.80 \pm 0.46$ & $11.08 \pm 0.16$ & $8.04 \pm 0.04$ & $9.71 \pm 0.11$ & $11.048 \pm 0.44$ \\
\hline $\begin{array}{l}\text { B (Lead acetate @ } 100 \text { mg/kg bwt in } 5 \\
\text { ml distilled water) }\end{array}$ & $520 \pm 8.29$ & $470 \pm 6.69$ & $345 \pm 6.69$ & $254.80 \pm 6.71$ & $122.80 \pm 2.93$ \\
\hline $\begin{array}{l}\text { C (Lead acetate @ } 100 \mathrm{mg} / \mathrm{kg} \text { bwt plus } \\
\text { Garlic extract@1 } 1 \mathrm{ml} / \text { mice in } 5 \mathrm{ml} \\
\text { distilled water) }\end{array}$ & $\begin{array}{l}260 \pm 4.00 \\
(50 \%)\end{array}$ & $\begin{array}{l}75 \pm 1.61 \\
(86.72 \%)\end{array}$ & $\begin{array}{l}70.20 \pm 1.77 \\
(79.65 \%)\end{array}$ & $\begin{array}{l}65.20 \pm 2.24 \\
(74.33 \%)\end{array}$ & $\begin{array}{l}90 \pm 3.40 \\
(26.71 \%)\end{array}$ \\
\hline $\begin{array}{l}\text { D (Lead acetate@ } 100 \mathrm{mg} / \mathrm{kg} \text { bwt plus } \\
\text { vitamin B-complex 40mg/kg bwt in } \\
5 \mathrm{ml} \text { distilled water) }\end{array}$ & $\begin{array}{l}290 \pm 3.57 \\
(44.23 \%)\end{array}$ & $\begin{array}{l}68 \pm 0.70 \\
(85.53 \%)\end{array}$ & $\begin{array}{l}82.00 \pm 0.44 \\
(76.23 \%)\end{array}$ & $\begin{array}{l}71.0 \pm 0.89 \\
(72.04 \%)\end{array}$ & $\begin{array}{l}105 \pm 3.84 \\
(14.49 \%)\end{array}$ \\
\hline $\begin{array}{l}\text { E (Lead acetate @ } 100 \mathrm{mg} / \mathrm{kg} \text { bwt plus } \\
\text { Garlic extract@ } 1 \mathrm{ml} / \mathrm{mice} \text { plus } \\
\text { vitamin B complex 40mg/kg bwt in } \\
5 \mathrm{ml} \text { distilled water) }\end{array}$ & $\begin{array}{l}215 \pm 2.60 \\
(58.65 \%)\end{array}$ & $\begin{array}{l}52 \pm 1.30 \\
(88.93 \%)\end{array}$ & $\begin{array}{l}45.80 \pm 1.46 \\
(86.72 \%)\end{array}$ & $\begin{array}{l}54.80 \pm 1.35 \\
(78.74 \%)\end{array}$ & $\begin{array}{l}87 \pm 2.30 \\
(29.15 \%)\end{array}$ \\
\hline
\end{tabular}

Values above represent the mean \pm SE of 5 mice, (\%) Indicate percent of decrease.

\section{REFERENCES}

1. Berney PJ, Cote LM and Buck WB (1994). Low blood lead concentration associated with various biomarkers in household pets. American Journal of Veterinary Research 55 (1): 55-62.

2. Bhattacharjee CR, Dey S and Goswami P (2003). Protective role of ascorbic acid against lead toxicity in blood of albino mice as revealed by metal uptake, lipid profiles, and ultrastructural features of erythrocytes. Bulletin of Environmental Contamination and Toxicology 70 (6): 1189-1196. 
3. Coffin DL (1955). Manual of Veterinary Clinical Pathology. $3^{\text {rd }}$ edn., Comsteck Publishing Associates. Inc. Ithaca New York. pp. 116-157.

4. Dhar A and Banerjee PK (1983). Impact of lead on nucleic acids and incorporation of leveled amino acid into protein. International Journal of Vitamin and Nutrition Research 53 (3): 349-354.

5. Deneke U, Rittersdorf W and Werner W (1985). Performance data of Reflotron-SGOT (AST) dry Chemistry test for Reflotron. Clinical Chemistry 31: 921.

6. Kamruzzaman (2006). Effects of ascorbic acid (vitamin c) and $\alpha$-tocopherol (vitamin E) in lead induced toxicities in rats. MS thesis, Department of Pharmacology, BAU, Mymensingh.

7. Haque MM (2005). Effects of calcium carbonate, potassium iodide and zinc sulfate in lead induced toxicities in mice. MS Thesis, Department of Pharmacology, BAU, Mymensingh.

8. Lamberg SL and Rothstein R (1977). Laboratory Manual of Hematology and Urinalysis. Avi. Publishing Company, Inc, West Port Connecticut, U.S.S.R.

9. Marchlewicz M, Wiszniewska B, Gonet B, Baranowska BI, Safranow K, Kolasa A, Glabowski W, Kurzawa R, Jakubowska K and Rac ME (2006). Increased Lipid Peroxidation and Ascorbic Acid Utilization in Testis and Epididymis of Mice Chronically Exposed to Lead. Biometals. pp.13.

10. Szymezak J, Zechalko A and Biernat J (1983). Effect of fodder fat type on blood plasma lipids in mice intoxicated with lead. Bromatol Chem Toksykol 16 (2): 98-94.

11. Tandon SK, Surendra S and Singh S (2000). Role of vitamins in treatment of lead intoxication. Journal of Trace Elements in Experimental Medicine 13 (3): 305-315.

12. WHO (1977). Environmental health criteria. 3. Lead. World Health Organization, Geneva.

13. Zayat EM, Yamany NA and Kamel ZH (1996). Combined supplementation of zinc and Garlic as protective agents against chronic lead toxicity in growing male albino mice. I-Liver functions. Journal of Egyptian General Society of Zoology 20 (A): 115-139.

14. Khan AQ (1989). Epidemiology and Disease control. $1^{\text {st }}$ edn., World University Service Press, Dhaka University Campus, Nilkhet, Dhaka. 